\title{
Lekkość śmiechu i ciężar grozy, czyli wyprawa w świat czeskich strachów
}

\section{Patrycjusz Pająk, Groza po czesku. Przypadki literackie, Wydział Polonistyki Uniwersytetu Warszawskiego, Warszawa 2014, 480 s.}

Książka Patrycjusza Pająka Groza po czesku. Przypadki literackie to obszerna (480 stron), imponująca bogactwem materiału monografia na temat zjawiska grozy w czeskiej literaturze. Warto podkreślić, że choć ukazało się wiele cząstkowych analiz fenomenu lęku w czeskich tekstach - na przykład interpretowane w rozprawie Vladimíra Papouška Existencialisté obrazy egzystencjalnej grozy w twórczości Jakuba Demla - nikt dotąd nie podjął się syntetycznego ukazania tego problemu, wpisanego w cezurę czasową rozpiętą między końcem XVIII wieku a współczesnością. Przy czym współczesność, choć bywa terminem elastycznie traktowanym, jest w tym przypadku najdosłowniej wspól-czesnością: w ostatnim rozdziale książki analizowane są utwory wydane w pierwszym dziesięcioleciu XXI wieku, ledwie kilka lat przed powstaniem omawianej monografii. Z tak szeroko zakrojonych zamiarów badawczych wynikają zarówno zalety, jak i słabości pracy. Za jej atut uważam ujęcie w jednym porządku analitycznym tekstów bardzo różnych, powstałych w odmiennych epokach i estetykach, prezentujących często niewspółmierny poziom artystyczny - taka decyzja dała sposobność pokazania historii czeskiego strachu w jego „długim trwaniu", w zmieniających się czasach i układach politycznych. Autor podkreślił historyczny proces przemian zjawiska grozy, pisząc o próbach zachowania w pracy porządku chronologicznego, co pozwoliło mu przedstawić kulturową dynamikę badanego fenomenu.

Nieczęsto mamy dziś do czynienia z tak rozległą monografią naukową: autorzy wolą wybierać mniejsze, a więc i mniej kontrowersyjne syntezy. W czasach humanistyki podejrzliwej nie tylko wobec własnych założeń 
epistemologicznych, ale wręcz wobec każdej przedstawionej tezy (bo ktoś ją już wygłosił lub mógł wygłosić), zdobycie się na ogromne, przekrojowe opracowanie to akt intelektualnej odwagi. Taki zakres tematu zmuszał autora do poruszania się po wielkim i zróżnicowanym polu historii czeskiej literatury i kultury, dodatkowo powiększonym przez kontekst europejski, to bowiem przede wszystkim prace najwybitniejszych europejskich myślicieli, zajmujących się problemem grozy, są dla Pająka narzędziami służącymi rozważaniu czeskich wariantów tego zjawiska.

Z materiałowego rozmachu i rozpiętości czasowej książki wynikają, jak już wspomniałam, także jej słabości. Bywa, że interpretacje poszczególnych utworów pozostawiają czytelnika (zwłaszcza specjalistę) z poczuciem niedosytu. Uwagi na temat epok bywają naznaczone pospiesznością, a nawet przybierają nadto oczywisty charakter. Metodologiczna przejrzystość pracy też może budzić wątpliwości. Autor synkretycznie podszedł do problemu metodologii, łącząc rozmaite metody, by pokazać możliwości odczytania zjawiska grozy w różnych jej rejestrach i przejawach. Był to, na co wskazują uwagi zawarte na stronie 28 , zamysł świadomy, odrzucający ograniczenia jednej wybranej metody badawczej. Synkretyzm wynikał poniekąd z decyzji o zajmowaniu się problemem grozy w tak dużym wycinku historii czeskiej literatury. W pewnych jednak przypadkach prowadziło to do aporii i sprzeczności prezentowanych teorii filozoficzno-socjologicznych na temat źródeł grozy i jej rozumienia. Szkoda, że w takich sytuacjach referencyjny tryb wywodu autora nie został uzupełniony o odautorski komentarz, odnoszący się do kontradykcji przywoływanych diagnoz.

Przyjęta przez autora metoda synkretyczna mimo wszystko się broni, jednak inne wątpliwości, które budzi metodologiczna strona pracy, nie zawsze zyskują jasną odpowiedź. Autor posłużył się dwiema strategiami. Przytacza teksty filozoficzne, psychologiczne i inne, współczesne lub bliskie czasowo analizowanym utworom, ukazujące, czego i jak bano się w danej epoce (wykorzystuje na przykład rozprawy Kierkegaarda, Schopenhauera), by potraktować je jako „klucze” do analizy, ale też jako komentarze do historycznego rozumienia strachu. Drugą strategią jest wykorzystanie - jako narzędzi analitycznych - rozpraw późniejszych wobec interpretowanego materiału literackiego, np. szkoły psychoanalizy zarówno w jej wersji klasycznej (Freud), jak i we współczesnych wariantach 
(Žižek) do odczytania grozy w utworach romantycznych. Obie strategie są prawomocne, jednak zabrakło nieco większej troski autora o wyłożenie warsztatowych intencji. Ponadto treści teoretyczne czasem przesadnie oddzielają się od analizowanego materiału literackiego. Odnosząc się do tekstów wpisanych w kanon kultury filozoficznej, należało też zadbać o bardziej wyraziste zaprezentowanie lektur pośredniczących, które wprowadzają w świat danej myśli filozoficznej. Tacy autorzy jak Schopenhauer, Kierkegaard, Nietzsche i inni, których pisma wykorzystuje Patrycjusz Pająk, ciągną za sobą, niczym komety, długi „ogon” odczytań, często nie mniej słynnych niż sam tekst kanoniczny. Przezorny filolog nie powinien stwarzać wrażenia, że Mistrzów tych czyta i cytuje „,po prostu”. Praca Pająka świadczy o dużej erudycji, oczytaniu i znajomości lektur ważnych dla humanisty, dlatego kładę to na karb warsztatowego potknięcia, zrozumiałego w przypadku tak długiej narracji naukowej (wspomniane już blisko 500 stron tekstu).

Osobną sprawą jest wybór analizowanych utworów literackich. Przy tak ogromnej literaturze podmiotu (obejmuje 256 pozycji, w tym 197 to dzieła czeskich autorów) wskazywanie, iż czegoś zabrakło, wydaje się niestosowne. Chodzi jednak o nieobecność - ledwie raz wzmiankowanego - Richarda Weinera, aczkolwiek jego utwory znakomicie nadają się do analizy zjawiska grozy, zarówno tej, którą ,serwuje” wojna, jak i grozy egzystencjalnej. Szanując prawa autora do osobistego wyboru tekstów, chciałabym jednak jako czytelniczka poznać reguły ich selekcji.

Przedstawione zastrzeżenia nie zmieniają faktu, że książka Groza po czesku. Przypadki literackie jest pracą nowatorską, zrealizowaną z niepospolitym i budzącym respekt rozmachem, zachowującą walory rozprawy naukowej, choć to rozprawa niepozbawiona popularyzatorskich atutów, dobrze napisana i ciekawa. Czytelnika spoza świata slawistycznego zapozna $\mathrm{z}$ istnieniem wielu mało znanych, a często niedostępnych w tłumaczeniu tekstów literackich. Slawiście otworzy oczy na nowe interpretacyjne konteksty i sprowokuje do przemyślenia przedstawionego przez autora obrazu czeskiej kultury.

Walorem monografii jest to, że choć mówi się w niej o „przypadkach literackich", nie ogranicza się do przedstawiania zjawisk z ekskluzywnie traktowanego świata literatury. Ten świat, bynajmniej nie autoteliczny, jest połączony żywą tkanką z polityką, zmianami społecznymi, ewolucją 
gustów. Utwory literackie są dla autora nie tylko Tekstem, ale też Zapisem, świadectwem zmieniającej się czeskiej świadomości kulturowej, rejestrem reakcji na zagrożenia wynikające z cywilizacyjnych przemian, a także dramatów historii (wojny, „czarny” i „czerwony” totalitaryzm). Autor dowodzi, że postrzeganie grozy jako elementu ludzkiej egzystencji w wymiarze zbiorowym i indywidualnym towarzyszyło czeskiej kulturze od jej odrodzenia w wieku XIX po współczesność. Ambicją autora, wyrażoną $\mathrm{w}$ pierwszym i rekapitulowaną w ostatnim rozdziale pracy, jest przedstawienie takiego obrazu wspomnianej kultury, który neguje stereotypową, ale wciąż - zwłaszcza w Polsce - aktualną wizję czeskiego świata jako rzeczywistości codziennej, oswojonej, na swój sposób przewidywalnej i bezpiecznej, nawet wtedy, gdy zmusza do zderzenia się z absurdami egzystencji. Istota tezy przedstawionej w książce polega na uznaniu, że jest to kultura nie tylko pogody i śmiechu, ale także strachu.

Na przekór rozpowszechnionym wyobrażeniom o czeskości, Patrycjusz Pająk pokazał w swojej książce inne jej oblicze, a na dowód przedstawił literaturę, w której świata nie daje się oswoić, ponieważ „lęk przenika przez ściany” (s. 19). Badacz pisze: „W nowoczesnej kulturze czeskiej - niezależnie od panującej sytuacji społeczno-politycznej - panuje dominanta kulturowa, którą można określić mianem biedermeierowskiej" (s. 10). Jednakże owa dominanta ma, co pokazuje autor, swój „,cień”. „Biedermeier prezentuje (...) świat oddemonizowany, ale jego nieodzownym uzupełnieniem, rodzajem cienia, jest gotycyzm, który - zamiast nobilitacji przeciętności i samoograniczenia - eksponuje skrajności i przekraczanie ograniczeń” (s. 430) i dalej: „Gotycyzm - jako cień biedermeieru - rozwija się równolegle do niego, a zarazem autonomicznie względem niego" (s. 431), aczkolwiek bywają też przypadki „biedermeierowsko-gotyckiej symbiozy" (s. 430-434).

Dla uzyskania wyrazistości kluczowej alternatywy „biedermeier groza" autor poddał biedermeierowską kulturę i jej wartości pewnemu retuszowi, podkreślającemu potrzebne mu cechy. Jeśli spojrzymy na obraz interesującej nas epoki, który przemawia choćby z kart wydanego $\mathrm{z}$ wielkim rozmachem albumu Biedermeier. Umění a kultura $v$ českých zemích 1814-1848 (Praha 2010), to okaże się, że standardowy obraz „kultury zacisza" poddawany jest obecnie rewizjom. Podobnemu retuszowi, z analogicznych powodów, Pająk poddał kanonicznego reprezentanta 
„uśmiechniętej czeskości” - Szwejka. Powyższe uwagi nie są jednak zarzutem. Autor jednoznacznie stwierdza, że jego ustalenia odnoszą się do form recepcji i postrzegania kultury, nie są opisem roszczącym sobie prawa do diagnozy kulturowej rzeczywistości. Można jednak polemizować z tym, czy formuła grozy była jedynym, a nawet podstawowym sposobem walki z usypiającym i obezwładniającym powietrzem biedermeierowskiego zacisza. Istniały przecież inne, literackie sposoby dyskredytowania idei „małego cichego domu”, w których ostrzem był nie strach, ale śmiech, a także pozaliterackie spory i niezwykle ostre dyskusje na temat „małego czeskiego człowieka”. Wystarczy przypomnieć kontrowersje wokół postaci Szwejka.

Badając różne poziomy tekstu literackiego i czynniki, za pomocą których ewokowany jest strach, badacz zajmuje się m.in. takimi elementami świata przedstawionego, jak czas i przestrzeń, konstrukcje bohaterów literackich, struktury narracyjne. Szeroki zakres badanych elementów tekstowych uzupełnia kontekst kulturowy, prezentujący różne sposoby rozumienia grozy: od lęku romantycznego (z jego średniowiecznymi i barokowymi korzeniami), pozytywistycznego, dekadenckiego, po strach czy raczej strachy współczesne. Autor udowadnia swe umiejętności sprawnej i interesującej analizy tekstu literackiego, choć nierzadko jego odczytania prowokują do dyskusji (co trudno poczytać za wadę). Potrafi weryfikować tezy dobrze utrwalone w historii literatury: przykładem jest rozdział poświęcony Jakubowi Arbesowi. Wbrew utartym opiniom, że konstrukcja tekstów Arbesa zmierza „od tajemnicy do rozjaśnienia”, co spełniałoby reguły pozytywistycznego obrazu świata, Pająk przekonuje czytelnika, że rozjaśnienie zagadki jest pozorne, w istocie zaś stajemy wobec innej, głębszej i mroczniejszej tajemnicy. Rozdział poświęcony twórczości Karla Hynka Máchy skłania do postawienia pytania, co w analizowanej przez Patrycjusza Pająka twórczości czeskiego romantyka wykraczało poza europejską fascynację tajemnicą, niesamowitością, irracjonalnością charakterystyczną dla tej epoki. Romantycy lubowali się w grozie, wyrażała to nie tylko ich literatura, ale także malarstwo, jednakże gdy groza okazywała się zbyt „groźna”, tj. wymykała się przyjętym konwencjom, pojawiały się kłopoty. Przykładem jest historia „opowiedziana” m.in. przez słynne płótno Théodore'a Géricaulta Tratwa „Meduzy”. Doświadczenia pasażerów francuskiej korwety „Meduza”, która zatonęła w roku 1816, wstrząsnęły 
Europą. Nie tylko dlatego, że kapitan statku i oficerowie odpłynęli na łodziach ratunkowych, zostawiając stu pięćdziesięciu osobom jedną tratwę, ale przede wszystkim z powodu tego, co działo się potem, podczas beznadziejnego dryfowania porzuconych. Spisaną przez dwóch ocalonych historię uznano za zbyt drastyczną, by ją publikować, a malarz, który dotarł do ich zeznań i przedstawił koszmar na malarskim płótnie, popadł w kłopoty. Czy taką „grozę poza konwencjami” pokazują analizowane przez Pająka teksty Máchy? Otóż nie, realizują one wzorce znane z europejskiej literatury i tylko sztafaż historyczno-geograficzny jest w nich „czeski”. A przecież w pewnych tekstach (np. fragmentach Maja), a także zapiskach, które poeta uznawał za prywatne, pojawia się groza przebijająca skorupę tolerowanych wówczas form. Szkoda, że te teksty nie zostały wykorzystane w książce Pająka.

Wszystkie te uwagi krytyczne i polemiczne nie podważają wartości publikacji Groza po czesku. Przypadki literackie. Skoro książka prowokuje do sporów, to już spełnia swą rolę. Rozprawa Patrycjusza Pająka jest jeszcze - bonus dla czytelnika - ciekawa. 